\title{
Yönetimde Değişen Duygu Zekâ İlişkisi Ve Yöneticilerin Duygusal Zekâ Düzeylerine İlişkin Bir Araştırma
}

\author{
Ramazan ARSLAN \\ İlknur MAZAN** \\ Erhan AYDIN ${ }^{* * *}$
}

\section{Özet}

Bu çalışma, duygu-zekâ ilişkisi konusunda yaşanan gelişmeler ve bu gelişmeler 1şığında ortaya çıkan duygusal zekâ kavramı ve duygusal zekânın yönetim ve yöneticiler üzerindeki etkilerini incelemeye yöneliktir. Geçmişte sadece aklın egemenliği üzerine kurulu düşüncelerle yönetilen örgütlerin, son yıllardaki değişim ve gelişmelere uyum sağlayamamaları, yöneticilerin duygu kavramına bakış açısını önemli ölçüde değiştirmiştir. Bu bağlamda, çalışmada duygu-zekâ kavramları arasındaki ilişki yönetsel tarih bakış açısıyla değerlendirilmiştir.

Çalışmada, Uşak ili hizmet sektöründe faaliyet gösteren üst ve orta düzey yöneticilerin kişisel nitelikleri ile duygusal zekâ yetenekleri birlikte ele alınarak duygusal zekânın yöneticiler üzerindeki etkileri belirlenmeye çalışılmıştır. Bu araştırma “Duygusal zekânın, Uşak'ta hizmet sektöründe faaliyet gösteren işletmelerin yöneticilerinin, duygularının farkında olma, duygularını anlamlandırabilme ve yönetebilme, başkalarının duygularını anlayabilme, motivasyonu sağlama ve örgüt içinde iletişimi ve sosyal ilişkileri sağlama yeteneklerine etkilerini " anlamaya yöneliktir.

Bu çerçevede araştırma, duygusal zekâ kavramının bir bütün olarak, değişime uyum sağlama ve insanlarla daha yoğun iletişim kurma hususlarına dikkat çekmesinden dolayı, değişimin en çok yaşandığı ve insanlarla en çok iletişim kurulan bir sektör olan hizmet sektöründe uygulanmıştır. Araştırmanın ana kütlesini Uşak ilinde faaliyet gösteren banka, otel işletmeleri, perakende sektöründeki kurumsallaşmış firmalar, seyahat acenteleri gibi hizmet sektörü alanında faaliyet gösteren işletmelerde görev yapan üst ve orta düzey yöneticiler, oluşturmaktadır.

\footnotetext{
* Yrd. Doç. Dr., Uşak Üniversitesi, İ.̇̇.B.F, İşletme Bölümü

** Öğr. Gör., Uşak Üniversitesi, Banaz Meslek Yüksekokulu

**** Arş. Gör., Uşak Üniversitesi, İ.İ.B.F , İşletme Bölümü
} 
Anahtar Kelimeler: Değişen Yönetim Anlayışı, Duygu-Zekâ İlişkisi, Duygusal Zekâ.

\title{
Changing Emotion- Intelligence Relationship In Management And A Research On Emotional Quotient Levels Of Managers
}

\begin{abstract}
This study is aimed at analyzing the resultant developments in the field of emotion-intelligence relationship and the impacts of emotional quotient concept on the managers. The fact that the organizations directing with the thoughts established just on mind have greatly changed the managers' viewpoint to the emotion concept. In this sense, the relationship between the emotion and intelligence concepts has been evaluated in the perspective of managerial history.

In this study, the impacts of emotional quotient on the managers by dealing with the individual characteristics of top and medium managers operating in Usak service sector. This research is aimed at determining the impacts of company managers working in Usak service sector on realizing, interpreting, understanding other people's emotions, providing motivation, communication in organizations and social relationships.

In this context, this research has been applied in service sector in which many changes occur and lots of people communicate because the emotional intelligence completely points out orientating to change and making contact with people intense. The population of study is consisted of the top and medium managers of banks, hotels, institutionalized retailing companies, tourism agents operating in Usak.

Key words: Changing Management Understanding, EmotionIntelligence Relationship, Emotional Intelligence

\section{Duygu-Zekâ İlişkisi Ve Duygusal Zekâ Kavramı}

İnsan davranışları ile ilgili araştırmalarda en çok tartışılan konulardan biri "duygu-zekâ" kavramları arasındaki ilişki olmuştur. Duygu ve zekâ kavramları arasındaki ilişkide alışılagelmiş anlayış; duyguyu zayıflık işareti ve karışıklık yaratan bir olgu olarak nitelendirmekte ve duyguların muhakemeyi engellediğini ya da yavaşlattığını ileri sürmektedir
\end{abstract}


(Ural, 2001: 212). Bu bağlamda duyguların insana zarar verebileceği ve iyi bir yaşam için "aklın ve mantığın kullanılması" gerektiği düşüncesi hâkim olmuştur.

Sanayi devrimiyle birlikte başlayan "aklın egemenliği" 20. yüzyllın başlarında psikoloji alanındaki gelişmelerle birlikte önemini kaybetmeye başlamıştır. Özellikle 1990'lı yılların başlarında, duyulardan gelen mesajların, neokortekse geçmeden önce, amigdaladan geçtiğinin bulunması ve biyolojik olarak Amigdala'nın beynin hafızaya ilişkin en önemli bölümü olarak nitelendirilmesi duygulara olan bakış açısını büyük ölçüde değiştirmiştir (Çakar, Arbak, 2004: 32). Bu bağlamda son yıllardaki araştırmalar, insanlarda duygusal ve akılcı süreçlerin birlikte hareket eden süreçler olduğu kabul etmekte ve insanların rasyonel olmaları kadar duygusal varlıklar olduğunu öne sürmektedirler.

Duygusal zekâ kavramını ilk kez ortaya koyan Meyer ve Salovey, 1990'lardaki gelişmelerin 1şı̆̆ında, duygusal yeteneklerin de zihinsel bir yetenek olduğunu ifade etmiştir. Meyer ve Salovey çalışmalarında duygusal zekâyı "bir insanın kendi duyguların ve başka insanların duyguların tanıyabilme, duygularım birbirinden ayırt edebilme ve bütün bu bilgileri, düşünce ve davranışların oluşumunda doğru bir biçimde kullanabilme yeteneği" şeklinde tanımlamaktadır. Meyer ve Salovey'in bu yaklaşımlarının getirdiği en önemli yenilik, "duyguları değişmesi zor olan kişisel özellikler olarak değil, geliştirilebilir yetenekler" olarak kabul etmeleridir (Mayer, 1990: 11).

Duygusal zekâ kavramının günümüzde en çok kullanılan tanımı Daniel Golemanın yaptığı tanımdır. Daniel Goleman'a göre duygusal zekâ, "kendi duygularmizı ve diğerlerinin duygularım anlama ve tanıma, kendi kendimizi motive etme, kendimiz ve başkaları ile ilişkilerimizde duygularımızı yönetme yeteneği"dir. Goleman, duygusal zekâyı "bütünüyle bilişsel yeteneklerle ölçülen, IQ olarak adlandırılan akademik zekâyı tamamlayıcı farklı yetenekler" şeklinde ifade etmektedir.

Tanımlardan da çıkarılabileceği gibi, duygusal zekâ öğrenilebilir sosyal ve psikolojik yeteneklerden oluşmaktadır. Bunlar; bireyin kendini ve duygularını tanıması, duyguların ifade edebilmesi, onlarda meydana gelen değişimleri kontrol altında tutabilmesi, karşılaştığı engellere karşı dirençli davranabilmesi, diğer bireylere anlayışla yaklaşabilmesi, onların duygularını fark edebilmesi, onlarla ilişki kurup, bu ilişkiyi sürdürebilmesi şeklinde sıralanabilir. 


\subsection{Duygusal Zekâ'nın Unsurları}

Duygusal Zekâ; özbilinç, özyönetim, motivasyon, empati ve sosyal beceriler olmak üzere beş unsurdan oluşmaktadır.

\subsection{1. Özbilinç}

Özbilinç, insanın duyguları, güçlü yanları ve sınırları ile değerleri ve dürtüleri hakkında derin bir anlayışa sahip olması anlamına gelmektedir. Özbilinci güçlü olan insanlar, ne kendilerini aşırı bir şekilde eleştirir ne de boş bir umuda kapılırlar. Bunun yanı sıra kendilerine ve başkalarına karşı dürüsttürler. Bu insanların sakin tavırları karar verme aşamasında ayrıntılı düşünmelerini sağlar. Böylece herhangi bir olayla ilgili farklı alternatifleri iyi bir şekilde değerlendirerek karar alabilirler (Goleman, Boyatzis, Mckee, 1997: 51).

\subsection{2. Özyönetim}

Kendini yönetme anlamına gelmektedir. Bu ise duygusal zekânın en önemli unsurlarından biridir. Çünkü; insan duyguları üzerinde hakimiyet kurmadıkça hem iç disiplinini sağlayamaz hem de yönetici pozisyonundaysa iyi bir yöneticilik yapamaz (Goleman, Boyatzis, Mckee, 1997: 57).

Gerek iş yaşamında gerek sosyal çevrede birçok olaydan etkilenebilen insan, olumlu ve olumsuz duyguyu bir arada yaşamaktadır. Ancak olumsuz duyguların oluşturacağı motivasyon eksikliği hem hayat içerisindeki kişisel performansı hem de iş yaşamındaki yönetici etkinliğini negatif yönde etkileyebilmektedir. Bunun için Özbilinç unsuru yüksek olan yöneticiler doğru zamanda ve yerde, doğru bir tepki verecek şekilde duygularını yönetebildiklerinden başarılı olurlar. (Acar, 2001: 44-45).

\subsubsection{Motivasyon}

Motivasyon, insanın hedeflere ulaşmasını sağlayan veya kolaylaştıran eğilimlerdir (Goleman, 2000: 144-145). Açlık, susuzluk, gibi fizyolojik kökenli güdülere dürtü adı verilir. İnsanlara özgü başarma isteği gibi yüksek dürtülere de ihtiyaç denir. Motivasyon sürecini anlamada ihtiyaçlar, dürtüler ve özendirici uyarcılar arasındaki ilişkiler ve anlamları önemlidir (http://www.kigem.com/content.asp?bodyID=3096 - 15.04.2008). 
Motivasyon, insanın hedeflere ulaşmasını sağlayan veya kolaylaştıran eğilimlerdir. Motivasyonu doğuran genel beyin devresini, amigdala barındırmaktadır. İnsanı başka etkinliklerden çok belirli bir etkinlik dizisinden zevk almaya yönelten duygusal öğrenim kadar, bu etkinliklerle bağlantılı bellek, his ve alışkanlık haznesi de amigdalanın duygusal bellek depolarında ve ilgili devrelerinde toplanmıştır. İnsanın en çok önem verdiği şeylere rehberlik eden amigdala, yaşamdaki önceliklerin karşılaştırılıp tartıldığı yerdir. Amigdalayı kaybetmeye yol açan beyin hastalıkları, bu hastalarda motivasyon bozukluğuna neden olmaktadır.

Motivasyon, başarma dürtüsü, kendini adamak, inisiyatif ve iyimserlik yeteneklerinden oluşmaktadır. Başarma dürtüsü, bir mükemmellik standardını yakalamaya veya yükseltmeye çalışmak; kendini adamak, grubun ya da kuruluşun hedeflerini benimsemek; inisiyatif, fırsatları değerlendirmek; iyimserlik, engellere ve yenilgilere göğüs germektir (Goleman, 2000: 144-145).

\subsubsection{Empati}

Empati birlikte hissetmek anlamına gelmektedir. Dürtüleri kontrol etmek ve bireysel sorumluluk almayla ilgilidir. Empati ve şefkat, duyguların ve deneyimlerin, sözlerin altındaki duruşun ve beden dilinin arkasındaki ortak dilin aracılığıyla, insanların birbirlerini daha iyi anlamasını sağlar. Kişinin empati duygusunun yüksek olması, duygusal zekâyı olumlu yönde etkiler ve verilecek olan herhangi bir kararda ya da tutumda daha adil bir davranış gösterilmesini sağlar (Cooper, Sawaf, 2000: 63-65).

\subsubsection{Sosyal Beceriler}

İnsanlarla iyi bir iletişim inşa etmek ve etkili bir iletişim kurmayı sağlayan yetenekler olarak nitelendirilmektedir (Cameron, 2006: 9) Sosyal becerileri düşük olan insanlar, kendi başlarına daha iyi çalışmakta, sosyal ortamlardan kaçmakta ve bu ortamlarda uyumsuz olmaktadırlar. Sosyal becerileri yüksek olanlar ise, iletişimde ve ekip çalışmalarında yeteneklidirler ve insanlarla bir araya geldiklerinde pozitif ilişkiler kurarlar (Cameron, 2006: 13).

Görüldüğü gibi ylllardır "iyi kişilik", "düzgün karakter", "yeterlilik", "esnek beceriler" ve "olgunluk" gibi farklı isimlerle anlatılan insanoğluna ait yetenekler aslında "Duygusal Zekâ"nın ta kendisidir (Goleman, 2000: 10). 


\section{Değişen Yönetim Anlayışında Duygu-Zekâ İlişkisi Ve Duygusal Zekâ}

Genellikle yönetim; evrensel bir süreç, toplumsal yaşam kadar eski bir sanat ve gelişmekte olan bir bilim olarak nitelendirilmektedir. Yönetim bu özellikleri ile değerlendirildiğinde; süreç olarak yönetim, bir takım faaliyet ve fonksiyonları; sanat olarak, bir uygulamayı; bilim olarak da, sistemli ve bilimsel bilgi topluluğunu ifade etmektedir (Koçel, 2001: 11).

Yönetim bilimi diğer disiplinler tarafından da farklı şekillerde tanımlanmaktadır. Ekonomistlere göre yönetim, toprak, sermaye ve işgücü ile birlikte üretim fonksiyonlarından birisidir. Yönetim bilimciler, yönetimin bir otorite sistemi olduğunu ifade ederler. Bunlara göre örgüt yöneten ve yönetilenler olmak üzere iki gruptan oluşur. Bu iki grup arasındaki ilişki otorite ilişkisidir. Toplumbilimciler ise yönetimi, bir sınıf ve saygınlık sistemi olarak nitelendirirler. Bu disiplinlerin dışında yönetimle ilgilenen; psikoloji ve hukuk gibi sosyal bilimlerin çeşitli dalları yönetimi, ilgi alanlarının amacına uygun bir biçimde tanımlamaya çalışmaktadırlar.

Çeşitli tanımlardan yola çıkarak yönetim, "belirlenmiş ortak amaçlara ulaşmak için başta insanlar olmak üzere parasal kaynakları, demirbaşları, donanımı, hammaddeleri ve zamanı verimli, etkin ve birbiriyle uyumlu olarak kullanabilecek kararlar alma ve uygulatma süreçleri toplamı" olarak da tanımlanabilir (Eren, 1993:3). Buna göre yönetim, ortak bir çaba, işbirliği ve eşgüdüme dayalı ussal bir etkinliktir. Bu yüzden yönetimin, işbirliği ve koordinasyona dayalı ussal bir grup etkinliği olduğunu söylemek mümkündür (Genç, 2004: 18).

Yönetsel tarihin gelişiminde, sanayi devrimi işletme ve yönetim düşüncesi bakımından son derece önemli değişme ve gelişmelerin yaşandığı bir dönemi ifade eder. Bu dönemde ekonomik faaliyetler ve işletmecilik alanında; el işi ile yapılan üretim yerini makine ile üretime bırakmış ve üretimde verimlilik artmış, iş bölümü bir zorunluluk haline gelmiş, birey sadece kendisi için ürettiğini artık pazar için üretmeye başlamış, üretim merkezileşmiş, merkezi üretimle birlikte yönetim ve örgütlenme problemleri ön plana çıkmış, sermaye birikimi ve toprak genişlemesinin yerini, üretim araçlarına sahip olma tercih edilir hale gelmiş ve üretimde finansman konuları daha çok önem kazanmıştır. Bu bağlamda modern üretim sistemlerinin yer almasıyla öneminin azaldığını hisseden insan, üretime katkısının çok az olduğunu, ortaya çıkan eserin sadece kendisine mal edilemeyeceğinin bilincinde olarak mutsuzlaşmıştır. (Eren, 1993: 9-12). 
Beşeri sorunların makineleşme ile hızla büyümesi, bu sorunların çözülmesine yönelik olan, farklı yönetim teorilerinin ortaya çıkmasına neden olmuştur (Ertürk, 2000: 6).

Bu teorilerden ilki olan Klasik Yönetim Teorisi, üç ana fikir etrafında gelişmiştir. Bunlardan ilki, insan unsurunun makineler yardımıyla etkin bir biçimde kullanılması, ikincisi, formel organizasyon yapısının bir düzen çerçevesinde oluşturulması ve sonuncusu ise, verimlilik ve etkinliğin sağlanabilmesi amacıyla kaynakların rasyonel olarak kullanılmasıdır (Genç, 2004: 52-53).

Klasik yaklaşım, örgütü kapalı ve mekanik sistemler olarak ele almış ve insan unsurunu rasyonellik açısından incelemiştir. Ayrıca, klasik yaklaşımın, insanı tabiatına aykırı bir şekilde tanımladığı ve üretim için duygusuz bir araç veya robot olarak değerlendirdiği görülmektedir (Genç, 2004: 53).

İkinci teori olan Neo-klasik Yönetim Teorisi, dikkatleri başka bir noktaya, "insan ilişkileri" ve "motivasyon" kavramlarına yöneltmiştir (Özalp, 1985: 20). Bu bağlamda iletişim, alg1, liderlik, motivasyon değişim, anlaşmazlık ve çatışmalar, ihtiyaç ve yetkilerin değişmesi ile davranışlarının değişmesi arasındaki ilişkileri anlamak daha çok önem kazanmıştır. Bu teoride, klasik yaklaşımın mekanik sistem tanımlamasının aksine, organizasyon sosyal sistemler olarak tanımlanmıştır. Grup davranışı ve iş görenlerin duygularının, üretimle olan ilişkisi çok sayıda araştırmaya konu olmuştur (Yüksel, 1998: 14). Özellikle klasik teorinin sadece yapısını oluşturmaya ağırlık verdiği "organizasyon" yerine, o organizasyonlarda çalışan insanların davranışlarını araştırarak yeni kavram, teknik ve uygulamalar önermiştir. Ancak yapılan çalışmalar derinlemesine değil yüzeysel bir nitelik göstermektedir. Çünkü bu teori organizasyonla ilgili sorunları sadece bir duygu sorunu olarak görmektedir. Ancak insan davranışarının her zaman duygusal bir temele dayanması söz konusu değildir. Bu bağlamda insan davranışlarının rasyonel boyutunun ihmal edilmemesi gerektiğidir (Genç, 2004: 70).

Üçüncü yönetim teorisi olan Modern Yönetim Teorisi, "Sistem Yaklaşımı" ve "Durumsallık Yaklaşımı" olarak, iki şekilde gelişmiştir. Modern yaklaşım, klasik yaklaşımın aksine, organizasyonu "organik bir yapı" olarak görmüştür. İnsan, makinenin bir parçası olarak değil, sistemin en önemli unsuru olarak ele almaktadır (Genç, 2004: 65). Durumsallık yaklaşımı, ilke 
ve kurallara göre değil de konjonktüre göre hareket etmesiyle, yönetimin faydacı ve pratik doğasına uygun düşmektedir. Yani, bu yaklaşıma göre geliştirilen yönetsel davranış modeli, zamanla sürekli değişecektir. Bunun nedeni, örgütsel ve çevresel koşulların sürekli değişmesidir. Bu yaklaşıma göre, yöneticiler, her şeyin değişebileceğinin bilincinde olmalı ve değişime ayak uydurmalıdırlar (Ertürk, 2000: 43).

Dördüncü teori Post-Modern Yönetim Teorisidir. Ekonomik ve teknolojik değişmelerin getirdiği sorunların çözümü için ortaya atılan görüşlerin uygulanmasıyla işgörenlerin başarıları azalmıştır. Bununla beraber, ilk kez zekâ, kişilik ve yetenek belirleyici testlerle daha nitelikli işgören bulma çabaları ile psikolojik uygulamalara başlanmış ve yirminci yüzyıl başlarında başlayan psikolojinin endüstriye uygulanması günümüze kadar büyük ölçüde gelişmiştir. İşören seçimiyle önem kazanan bu konu daha sonra pazarlamada reklam ve satış sorunlarının psikolojik yönlerine çevrilmiştir (Eren, 1993: 10).

Yönetim teorilerinde görüldüğü üzere, örgütler uzun bir süre duygu-zekâ ilişkisi konusunda, akılcılığı savunan klasik yaklaşımların etkisinde kalmıştır. Sanayi devrimiyle artan büyük ölçekli işletmelerin, akılcılığın gücünü daha da artırdığı ve klasik yönetim teorisiyle, örgütlerde duyguların kontrol edilmeye çalışıldığı görülmektedir. Fakat daha sonraları, akılcılık yaklaşımının aksine, duygu kavramına önem verildiği görülmektedir. İnsanı; duyguları, sosyal ihtiyaçları, sosyal çevresi ve motivasyonu ile bir bütün olarak ele almıştır. Yöneticiler, dikkatlerini daha çok işgörenlerin duygusal yanlarına yoğunlaştırmışlardır (Saraoğlu, 2003: 8).

Örgütlerin bakış açısı, klasik yönetim teorisindeki gibi insanın üretim sürecinin girdilerinden biri olduğu görüşünden, insanın ve onun duygu ve düşüncelerinin örgütün en önemli değerleri olduğu görüşüne dönüşmeye başlamıştır. Bu noktada, kurumsal zekânın, eskiden olduğu gibi yalnızca IQ ve matematiksel modellerden oluşmayacağı, duygusal zekânın ve biyolojik ilkelerin daha çok dikkate alınacağını gösteren işaretler görülmektedir (Çakar, Arbak, 2004: 44).

\section{Araştırmanın Amacı}

Yönetimde, öncelikle belirli bir amaca başkalarıyla birlikte ulaşma, başkalarına iş gördürme ve onların yardımlarını sağlama söz konusudur. Genel bir tanımla yönetici "başkaları vasıtasıyla iş gören kişidir". (Koçel, 2001: 
16). Daha ayrıntılı bir tanımla ise yönetici, "emrine verilmiş insan grubunu belirli amaçlara ulaştırmak için işbirliği ve ahenk içinde yönlendiren kişidir" (Dinçer, Fidan, 1999: 31).

Sürekli değişen ve gelişen bir çevrede faaliyet gösteren işletmelerin yapı ve uygulamalarında meydana gelen değişimler, yöneticilerin sahip oldukları yetenekleri de değişime zorlamaktadır. Bu bağlamda günümüze kadar yalnızca teknik yetenekleri gelişmiş yöneticiler başarılı olurken, günümüzde diğer yeteneklerin de önem kazanmaya başladığ görülmektedir (Dalay, 2001: 49).

$\mathrm{Bu}$ araştırmanın amacı, yöneticilerin özbilinç, özyönetim, empati, motivasyon ve sosyal becerilerden oluşan duygusal zekâ yetkinliklerine sahip olup olmadıklarını incelemektir. Bu araştırma "Duygusal zekânın, Uşak'ta hizmet sektöründe faaliyet gösteren işletmelerin yöneticilerinin, duygularının farkında olma, duygularını anlamlandırabilme ve yönetebilme, başkalarının duygularını anlayabilme, motivasyonu sağlama ve örgüt içinde iletişimi ve sosyal ilişkileri sağlama yeteneklerine etkilerini " anlamaya yöneliktir.

\section{Araștırmanın Örneklemi Ve Sınırları}

Bu çalışmada, Uşak'ta hizmet sektöründe faaliyet gösteren yöneticilerin kişisel niteliklerine ilişkin bir uygulama gerçekleştirilmiştir. Bu yöneticilerin duygusal zekâ yetenekleri ele alınarak duygusal zekânın yöneticiler üzerindeki etkileri belirlenmeye çalışılmıştır. Araştırmanın ana kütlesini Uşak'ta, banka, otel işletmeleri, perakende sektöründeki kurumsallaşmış firmalar, seyahat acentaları gibi hizmet sektörü alanında faaliyet gösteren işletmelerde görev yapan toplam 95 üst ve orta düzey yöneticiler, oluşturmaktadır.

Bu araştırma, duygusal zekâ kavramının bir bütün olarak, değişime uyum sağlama ve insanlarla iletişim hususlarına dikkat çekmesinden dolayı, değişimin en çok yaşandığı ve insanlarla en çok iletişim kurulan bir sektör olan hizmet sektörünün yöneticileri üzerinde uygulanmıştır.

\section{Araştırmanın Yöntemi}

Hizmet sektöründe faaliyet gösteren işletmelerin yöneticilerinin duygusal zekâ yeteneklerini ölçmek amacıyla, doküman incelemesi ve 
araştırılması yapılmış, bu bağlamda 30 sorudan oluşan bir anket formu hazırlanmıştır. Bilgi toplama aracı olarak kullanılan anket, "Robert Cooper ve Ayman Sawaf" tarafından geliştirilen EQ Haritası'ndan uyarlanmıştır.

Anket formu iki bölümden oluşmaktadır. Birinci bölümde, yöneticilerin kişisel bilgilerine ilişkin 4 soru ve ikinci bölümde yöneticilerin duygusal zekâ yeteneklerini belirlemeye yönelik 30 soru yer almaktadır. Bu ankette özbilinç, özyönetim, empati, motivasyon ve sosyal beceriler boyutları yer almaktadır. Anketten elde edilen verilerin SPSS 19 programında yapılan geçerlilik analiziyle (faktör analizi) hangi soruların hangi boyutlar altında yer aldığı gösterilmiştir.

Anketin ikinci bölümünde yer alan sorular 4'lü likert ölçeği formatına göre hazırlanmıştır. Sıklık düzeyi "asla, bazen, genellikle, her zaman" olmak üzere sıralanmıştır. Anketin uygulanması aşamasında, karşılıklı görüşme yöntemi uygulanmış ve 95 kişiden 80 kişiye ulaşılabilmiştir. Bu geri dönüşüm sağlanamayan grup içerisinde ankete cevap vermek istemeyen yöneticilerin yanında, gidildiğinde yerinde bulunamayıp anket formu bırakılan ve geri dönüş alınamayan yöneticiler de vardır.

Elde edilen verilerin genel analizi SPSS 19 programında yapılarak yorumlanmıştır.

\section{Araştırmanın Bulguları}

\subsection{Yöneticilerin Kişisel Niteliklerine İlişkin Frekans Analizi}

\begin{tabular}{|c|c|c|}
\hline POZİSYON & Siklık & Yüzde (\%) \\
\hline Üst düzey yönetici & 25 & 32 \\
\hline Orta düzey yönetici & 55 & 68 \\
\hline TOPLAM & 80 & 100 \\
\hline \multicolumn{3}{|l|}{ EĞİTIM DÜZEYİ } \\
\hline Lise & 26 & 32,5 \\
\hline Önlisans & 1 & 1,3 \\
\hline Lisans & 45 & 56,3 \\
\hline Yüksek Lisans & 8 & 10 \\
\hline TOPLAM & 80 & 100 \\
\hline
\end{tabular}


Uşak Üniversitesi Sosyal Bilimler Dergisi

$2013,6 / 3$

R. ARSLAN, I. MAZAN, E. AYDIN

\begin{tabular}{|l|c|c|}
\hline EĞİTiM ALANI & & \\
\hline İşletme - İktisat & 26 & 32,5 \\
\hline Mühendislik & 4 & 5 \\
\hline Hukuk & 1 & 1,3 \\
\hline Diğer & 49 & 61,3 \\
\hline \multicolumn{1}{|c|}{ TOPLAM } & $\mathbf{8 0}$ & $\mathbf{1 0 0}$ \\
\hline KIDEM & 55 & \\
\hline $0-5$ Y1l & 19 & 68,8 \\
\hline $6-10$ Y1l & 4 & 23,8 \\
\hline $11-15$ Y1l & 2 & 5 \\
\hline 16 Y11 ve Üzeri & $\mathbf{8 0}$ & $\mathbf{1 0 0}$ \\
\hline TOPLAM & & \\
\hline
\end{tabular}

Kuruluştaki pozisyona bakıldığında, anketi cevaplayanların 20'si $\% 25^{\prime}$ lik oranla üst düzey yönetici; $60^{\prime} 1 \% 75^{\prime}$ lik oranla orta düzey yöneticidir. Anketi cevaplayanların 26'sı, bir başka deyişle \%32,5'lik kısmı lise mezunu iken, \%1,3'ü ön lisans, \%56,3'ü lisans, \%10'u yüksek lisans mezunudur. Lisans mezunu olan yöneticilerin, anketi cevaplayanların \%56,3'lük bir kesimini oluşturduğu görülmektedir. Buradan, yüksek eğitim düzeyinin yönetici olma konusunda bir zorunluluk olmadığı söylenebilir. Anketi cevaplayanların eğitim düzeylerinin lisans ve lise olarak yoğunlaştığ görülmektedir.

Ankete katılanların 26'sı \%32,5'lik bir oranla işletme-iktisat alanında, 4'ü \%5'lik bir oranla mühendislik alanında, 1'i \%1,3'lük bir oranla hukuk alanında, 49'u \%61,3'lük bir oranla diğer alanlarda eğitim almışlardır. Burada, yöneticilik yapanların sadece \%32,5'lik bir kısmının işletme alanında eğitim aldıkları görülmektedir. Bu durum, işletme alanında eğitim almayanların da yöneticilik yaptığını göstermektedir. \%68,8'lik bir dilim, bir başka deyişle ankete katılanlardan $55^{\prime}$ i, firmada 0 ve 5 yıl arasında değişen iş deneyimine sahiptirler.

Firmadaki deneyimi 6 ile 10 yıl arasında olanlar, \%23,8'lik bir oranla 19 kişidir. 11 ile 15 yıl arasında deneyimi olan 4 kişi, 16 ve üzeri deneyimi olan 2 kişi vardır. Bu tabloda, Uşak'ta hizmet sektöründe faaliyet gösteren işletmelerin yöneticilerinin, genellikle lise veya lisans mezunu olduğu görülmektedir. 
Uşak Üniversitesi Sosyal Bilimler Dergisi

$2013,6 / 3$

R. ARSLAN, I. MAZAN, E. AYDIN

Ayrıca, kıdeme bakıldığında, çalışmakta oldukları işyerlerinde 0-5 yıl tecrübesi olanların çoğunlukta olmasının, perakende alanında faaliyet gösteren bazı işletmelerin yeni açılmış olması ve hizmet sektöründe iş gören devir hızının fazla olmasından kaynaklandığı düşünülmektedir.

\subsection{Kullanılan Ölçeğin Güvenilirliği}

Duygusal zekâ yeteneklerini belirlemeye yönelik kullanılan ölçeğin güvenilirliği (cronbach alpha değeri) 0,667 'dir. Ancak uygulanan sorular üzerinde madde analizi uygulanmış olup, sonuçlar tablo 1'de gösterilmiştir.

\begin{tabular}{|c|c|c|c|c|}
\hline & $\begin{array}{l}\text { Scale Mean if } \\
\text { Item Deleted }\end{array}$ & $\begin{array}{c}\text { Scale } \\
\text { Variance if } \\
\text { Item Deleted }\end{array}$ & $\begin{array}{l}\text { Corrected } \\
\text { Item-Total } \\
\text { Correlation }\end{array}$ & $\begin{array}{l}\text { Cronbach } \\
\text { 's Alpha } \\
\text { if Item } \\
\text { Deleted }\end{array}$ \\
\hline S1 & 79,1000 & 96,041 & ,466 &, 646 \\
\hline $\mathrm{s} 2$ & 79,1625 & 96,163 & ,447 & ,647 \\
\hline s3 & 79,0375 & 95,733 & ,504 & ,644 \\
\hline s4 & 79,2750 & 95,746 & 363 & ,648 \\
\hline s5 & 79,3750 & 95,123 & ,502 & ,643 \\
\hline s6 & 79,6875 & 94,167 & ,508 & ,640 \\
\hline s7 & 79,0875 & 99,499 & ,178 & 661 \\
\hline s8 & 80,7375 & 105,715 &,- 211 & ,682 \\
\hline s9 & 80,9875 & 104,924 &,- 178 & ,677 \\
\hline $\mathrm{s} 10$ & 79,6125 & 96,266 &, 406 & ,648 \\
\hline s11 & 78,9375 & 97,857 & ,308 & ,654 \\
\hline s12 & 79,0750 & 93,387 &, 545 & 637 \\
\hline $\mathrm{s} 13$ & 79,1750 & 97,311 & ,390 & ,651 \\
\hline s14 & 79,4500 & 96,757 & ,389 & ,649 \\
\hline s15 & 79,5500 & 96,301 &, 420 & 648 \\
\hline s16 & 80,1750 & 103,361 &,- 058 & 676 \\
\hline s17 & 79,6250 & 98,870 & 251 & 657 \\
\hline $\mathrm{s} 18$ & 80,4875 & 106,506 &,- 229 & ,687 \\
\hline s19 & 79,6750 & 99,589 & 223 & ,659 \\
\hline $\mathrm{s} 20$ & 80,5000 & 103,620 &,- 076 & 680 \\
\hline s21 & 79,7000 & 100,567 & 154 & ,663 \\
\hline s22 & 80,8375 & 100,568 & , 126 & ,664 \\
\hline s23 & 79,7250 & 100,025 & , 135 & 664 \\
\hline
\end{tabular}


Uşak Üniversitesi Sosyal Bilimler Dergisi

$2013,6 / 3$

R. ARSLAN, I. MAZAN, E. AYDIN

\begin{tabular}{|r|r|r|r|r|}
\hline s24 & 79,7625 & 66,133 &, 241 &, 769 \\
\hline s25 & 79,6375 & 101,069 &, 078 &, 667 \\
\hline s26 & 78,8500 & 97,471 &, 387 &, 651 \\
\hline s27 & 79,4750 & 96,430 &, 496 &, 646 \\
\hline s28 & 79,6250 & 93,326 &, 553 &, 637 \\
\hline s29 & 79,3750 & 96,946 &, 483 &, 648 \\
\hline s30 & 79,5375 & 97,315 &, 441 &, 650 \\
\hline
\end{tabular}

Yukarıda belirtilen madde analizi neticesinde, soru 24'ün anketten çıkarıldığında, anketin yeni güvenilirlik düzeyinin (cronbach alpha) değerinin 0,769 'a yükseleceği görülmektedir. Bu amaçla, bu soru anketten çıkarılarak analizlere devam edilmiştir.

\subsection{Kullanılan Ölçeğin Geçerliliği}

Kullanılan anketin geçerliliğini tespit etmek amacıyla, faktör analizi uygulamasına gidilmiştir. Bu uygulamanın yapılmasından önce, ankette yer alan soruların faktör analizinin uygulanmasına uygun olup olmadığının anlaşılması için KMO (Kaiser- Meyer- Oklin) katsayısı hesaplanmıştır.

Bu çalışma için bu katsayının değeri 0,689' dur. Bu da verilerin, faktör analizlerinin yapılacağını göstermektedir. Çünkü bu değer $0,6^{\prime}$ dan büyük olmak zorundadır. Bunun yanı sıra Barlett testi değişkenler arasında bir ilişkinin olup olmadığını belirlemektedir. Bu değer ise çalışma için 0,00 düzeyinde istatistiksel olarak anlamlı çıkmıştır.

Tüm bu verilerin ışığında ölçeğe uygulanan faktör analizine ilişkin sonuçlar tablo 2' de gösterilmiştir.

\begin{tabular}{|c|l|l|l|l|l|}
\hline \multirow{7}{*}{} & \multicolumn{5}{|l|}{ Tablo 2: Faktör Analizi Sonuçları } \\
\hline & 1 & 2 & 3 & 4 & 5 \\
\hline s2 &, 823 & & & & \\
\hline S1 &, 803 & & & & \\
\hline s3 &, 775 & & & & \\
\hline s4 &, 747 & & & & \\
\hline s5 &, 661 & & & & \\
\hline s13 &, 575 & & & & \\
\hline s15 &, 502 & & & & \\
\hline s16 & &, 806 & & & \\
\hline
\end{tabular}


Uşak Üniversitesi Sosyal Bilimler Dergisi

$2013,6 / 3$

R. ARSLAN, I. MAZAN, E. AYDIN

\begin{tabular}{|c|l|l|l|l|l|}
\hline $\mathrm{s} 20$ & &, 759 & & & \\
\hline $\mathrm{s} 18$ & &, 605 & & & \\
\hline $\mathrm{s} 22$ &, 557 & & & \\
\hline $\mathrm{s} 9$ & &, 528 & & & \\
\hline $\mathrm{s} 14$ & &,- 486 & & & \\
\hline $\mathrm{s} 19$ & & &, 798 & & \\
\hline $\mathrm{s} 10$ & & &, 640 & & \\
\hline $\mathrm{s} 11$ & & &, 613 & & \\
\hline $\mathrm{s} 21$ & &, 590 & & \\
\hline $\mathrm{s} 17$ & &, 450 & & \\
\hline $\mathrm{s} 12$ & & &, 429 & & \\
\hline $\mathrm{s} 6$ & & &, 405 & & \\
\hline $\mathrm{s} 27$ & & & &, 647 & \\
\hline $\mathrm{s} 7$ & & & &, 618 & \\
\hline $\mathrm{s} 26$ & & & &, 603 & \\
\hline $\mathrm{s} 30$ & & & &, 549 & \\
\hline $\mathrm{s} 28$ & & & &, 539 & \\
\hline $\mathrm{s} 29$ & & & & &, 741 \\
\hline $\mathrm{s} 25$ & & & & &, 340 \\
\hline $\mathrm{s} 23$ & & & & & \\
\hline $\mathrm{s} 8$ & & & & & \\
\hline
\end{tabular}

Yapılan faktör analizi ışığında boyutların içerdiği sorular tablo 3 'te gösterilmiştir.

Tablo 3: Boyutlara İlişkin Sorular

\begin{tabular}{|c|c|c|c|c|}
\hline Özbilinç & Empati & Özyönetim $^{\text {Sosyal }}$ & $\begin{array}{l}\text { Motivasyon } \\
\text { Beceriler }\end{array}$ \\
\hline 1 & 9 & 6 & 7 & 8 \\
\hline 2 & 14 & 10 & 26 & 23 \\
\hline 3 & 16 & 11 & 27 & 25 \\
\hline 4 & 18 & 12 & 28 & \\
\hline 5 & 20 & 17 & 29 & \\
\hline 13 & 22 & 19 & 30 & \\
\hline 15 & & 21 & & \\
\hline
\end{tabular}




\subsection{Yöneticilerin Duygusal Zekâ Düzeyleri}

Uygulanan anketin içerdiği beş boyuta göre pozisyonlara göre düzeyler tablo 4 de belirtildiği gibidir.

Tablo 4: Hizmet Sektöründe Yöneticilerin Duygusal Zekâ Düzeyleri

\begin{tabular}{|l|l|r|r|}
\hline & Pozisyon & $\mathrm{N}$ & Ortalama \\
\hline \multirow{2}{*}{ Özbilinç } & Üst düzey yönetici & 25 & 3,2857 \\
\cline { 2 - 4 } & Orta düzey yönetici & 55 & 3,0857 \\
\hline \multirow{2}{*}{ Empati } & Üst düzey yönetici & 25 & 2,0400 \\
\cline { 2 - 4 } & Orta düzey yönetici & 55 & 1,9545 \\
\hline \multirow{2}{*}{ Özyönetim } & Üst düzey yönetici & 25 & 2,8971 \\
\cline { 2 - 4 } & Orta düzey yönetici & 55 & 2,9221 \\
\hline \multirow{2}{*}{ Sosyal beceriler } & Üst düzey yönetici & 25 & 3,1667 \\
\cline { 2 - 4 } & Orta düzey yönetici & 55 & 3,0152 \\
\hline \multirow{2}{*}{ Motivasyon } & Üst düzey yönetici & 25 & 2,2667 \\
\cline { 2 - 4 } & Orta düzey yönetici & 55 & 2,3939 \\
\hline
\end{tabular}

Tablo 4 'te görüldüğü üzere, analiz edilen örneklem içerisinde üst yöneticilerin özbilinci, empati düzeyi ve sosyal becerileri orta düzey yöneticilere göre daha yüksekken; orta düzey yöneticilerin özyönetim ve motivasyon düzeyi üst düzey yöneticilere göre daha yüksektir.

Genel olarak bu beş boyutun değerlendirilmesi yapıldığında, hizmet sektöründe faaliyet gösteren bu yöneticilerin, yönetme ve organizasyondaki yürütme işlemi ele alındığında duygusal zekânın öneminin büyük olduğu görülmektedir. Çünkü özbilince sahip olan, empati yapabilen, özyönetim diğer bir değişle iç disiplini olan, sosyal beceriler açısından gelişmiş ve motivasyonu yüksek olan yöneticiler, iş ortamında huzurun yanı sıra etkin bir işleyişi de sağlamaktadır.

\section{Sonuç}


Görüldüğü üzere, sanayi devrimiyle başlayan ve devam etmekte olan, insanlığ tamamen sarmalayan teknolojik gelişmeler, bitmek bilmeyen değişmeler, bunlar sonucunda azalan mesafeler, artan iletişim ve değişime uyum sağlama, kendini sürekli yenileme zorunluluklarıyla beraber, duygu zekâ ilişkisi irdelenmeye başlamıştır. Duyguları devre dışı bırakan yönetim sistemi, çalışanların psikolojik sorunlar yaşamalarına, uyum sorunlarına, çatışmalara ve yabancılaşmalarına neden olmaktan başka bir sonuç getirmemiştir. Son dönemlerde yaşanan sürekli değişime uyum sağlayabilmek, duyguları bir kenara bırakmakla mümkün olmamaktadır. Çünkü duygular, muhakemeyi sağlamada, doğru kararlar vermede, uyum sağlamada ve iletişim kurmada son derece önemli bir yere sahiptirler.

Duyguyla zekânın harmanlanmasından oluşan duygusal zekânın ortaya çıkısı ve gelişimi, yönetim alanındaki gelişmelerle tarih bakımından paralellik göstermektedir. Kendi duygularının farkında olma, duyguları yönetebilme, başkalarının duygularının farkında olma, motivasyon ve sosyal beceriler unsurlarından oluşan duygusal zekâ, günümüz yönetim anlayışının ve yöneticilerinin sahip olması gereken özelliklerle uyum içerisindedir. Duygusal zekâsı yüksek olan kişiler, değişime kolay adapte olabilen, kendini tanıyan, geliştirebilen, stres, öfke gibi kötü duygularını bastırıp, olumlu duygulara dönüştürebilen, başkalarını anlayabilen, motivasyonu sağlayabilen ve iletişimi iyi olan, liderlik yapabilen kişilerdir. $\mathrm{Bu}$ yetenekler ise, günümüz yönetim anlayışının vazgeçilmez unsurlarındandır.

Çalışmadaki araştırmanın sonuçları, yöneticilerin duygusal zekâ düzeylerinin yüksek olduğunu göstermektedir. Anket incelendiğinde, Uşak'ta hizmet sektöründe faaliyet gösteren işletme yöneticilerinin duygusal zekâlarının genel itibariyle yüksek olduğu görülmektedir. Ayrıca, görüşmelerden elde edilen sonuca göre, çoğunun duygu - zekâ ilişkisi ve duygusal zekâ konularına ilgi gösterdikleri ve duygusal zekâdan haberdar oldukları anlaşılmaktadır. Duygusal zekâdan haberdar olanların, kendilerini sürekli yenileyen ve değişime uyum sağlayabilen kişiler oldukları, dolayısıyla duygusal zekâ yeteneklerinin de gelişmiş olduğu söylenebilir.

Mutsuz bir çalışan, insanlarla sürekli iletişim içinde olacağından, müşterilere bu duygusunu yansitacaktır. Hizmet sektörü yöneticileri, bu yüzden duygusal zekâya daha çok ihtiyaç duymaktadırlar. Klasik tarzda, asık suratlı, sert ve duygulardan arınmış bir yönetici, hizmet sektöründe, özellikle günümüzde başarıya ulaşamayacaktır. 
Duygusal zekâsı yüksek olan yönetici ise, özbilinç ve özyönetim sahibi olan, empati kurabilen ve motivasyonu sağlayan, kendini sürekli yenileyen, iletişimi ve sosyal becerileri kuvvetli, dolayısıyla liderlik vasfına sahip yöneticidir. Bu yöneticinin, özellikle hizmet sektöründe, liderlik ettiği grupla beraber başarıya ulaşmaması için hiçbir engel yoktur.

Çalışmadan yola çıkılarak, günümüz yöneticilerinin, duygularının farkında olan ve onları yönetebilen, çalışanlarını dinleyen ve onların başarılarını ödüllendiren, gerektiğinde astlarından yardım isteyebilen, kendine güveni yüksek ve iletişimi iyi olan, yenilikçi ve lider vasıflı kişiler olması gerektiğini söylemek mümkündür.

\section{Kaynakça}

ACAR Füsun Tekin, "Duygusal Zekâ Yeteneklerinin Göreve Yönelik ve İnsana Yönelik Liderlik Davranışları İle İlişkisi: Banka Şube Müdürleri Üzerine Bir Alan Araştırması", (Yayınlanmamış Doktora Tezi), İstanbul Üniversitesi, Sosyal Bilimler Enstitüsü, İşletme ve Personel Yönetim - Organizasyon Doktora Programı, İstanbul, 2001.

CAMERON Allan, "WPQei User's Guide Emotional Intelligence Personality Team Roles", Hogrefe Ltd., 2006 (http://www.cimtp.com/WPQei\%20User\%20Guide\%202004\%20Revi sion.pdf -13.01.2008)

COOPER Robert K. , SAWAF Ayman, Liderlikte Duygusal Zekâ, Sistem Yayıncılık, B.2 İstanbul, 2000.

ÇAKAR Ulaş, ARBAK Yasemin, Modern Yaklaşımlar Işı̆̆ında Değişen Duygu Zekâ İlişkisi ve Duygusal Zekâ, Dokuz Eylül Üniversitesi Sosyal Bilimler Enstitüsü Dergisi, C. 6, S. 3, 2004.

DALAY İsmail, Yönetim ve Organizasyon, İlkeler, Teoriler ve Stratejiler, Sakarya Üniversitesi Yayını, Adapazarı, 2001.

DINÇER Ömer, FIDAN Yahya, İşletme Yönetimine Giriş, B.4, Beta Yayınevi, İstanbul, 1999.

EREN Erol, Yönetim ve Organizasyon, B. 2, Beta Yayım, İstanbul, 1993. 
Uşak Üniversitesi Sosyal Bilimler Dergisi

$2013,6 / 3$

R. ARSLAN, I. MAZAN, E. AYDIN

ERTÜRK Mümin, İşletmelerde Yönetim ve Organizasyon, B. 3, Beta Basım, İstanbul, 2000.

GENÇ Nurullah, Yönetim ve Organizasyon-Çağdaş Sistemler ve Yaklaşımlar, Seçkin Yayıncılık, Ankara, 2004.

GOLEMAN Daniel, BOYATZIS Richard, MCKEE Annie, Yeni Liderler, B.3, Varlık Yayınları, İstanbul, 1997.

GOLEMAN Daniel, İşbasında Duygusal Zekâ, B.3, Varlık Yayınları, İstanbul, 2000.

KOÇEL Tamer, İşletme Yöneticiliği, B. 8, Beta Basım, İstanbul, Mart 2001.

MAYER J.D., Emotional Intelligence, Baywood Publishing Co. Inc. , 1990.

ÖZALP İnan, İşletmelerde Yönetim, Fonksiyonlar ve Organizasyon, Bayteş Yayınları, Ankara, 1985.

SALOVEY, MAYER, GOLDMAN, Turyey and Palfai, 1995 (http://www.eq.org/cgi/frames.pl?id=130\&title=EQ\%20Quote\%20Lib rary - Some EQ Quotes - 22.02.2008)

SARAOĞLU Şerif, İşletme Yönetiminde İnsan Kaynaklarının Duygusal ve Zihinsel Becerilerinin Yönetim Başarısına Etkisi ve Bir Uygulama, (Yayınlanmamış Doktora Tezi, Dumlupınar Üniversitesi Sosyal Bilimler Enstitüsü, İşletme Yönetimi Anabilim Dalı Doktora Programı), Kütahya, 2003.

URAL Ayhan, Yöneticilerde Duygusal Zekâ'nın Üç Boyutu, Dokuz Eylül Üniversitesi Sosyal Bilimler Enstitüsü Dergisi Cilt 3, Sayı 2, 2001.

YÜKSEL Öznur, İnsan Kaynakları Yönetimi, 2. Baskı, Gazi Kitabevi, Ankara, 1998.

(http://www.kigem.com/content.asp?bodyID=3096 - 20.12.2011) 